\title{
THE EXPANDED USUL OF VIOLENCE BY ISIS, AL-QAEDA, AND OTHER SIMILAR EXTREMIST GROUPS
}

\author{
Omar Suleiman* \\ Elmira Akhmetova**
}

\begin{abstract}
This paper discusses the methodology of violence used by modern extremist groups that affiliate themselves with Islam, particularly al-Qaeda and ISIS. With the rise of groups claiming to wage jihad, the public has a difficult time discerning traditional concepts from modern aberrations. Furthermore, the groups themselves seem to be alike. The examination of the legal framework used by these groups to justify their violent practices shows a dishonest usage of the traditions they claim to defend. This becomes most obvious with the rise of ISIS, which claims to manifest concepts beyond jihad, such as bay'ah and jizyah. It is also highlighted in the paper that the selective readings of these groups take the most violent interpretations of numerous issues and reduces every target to a disbeliever worthy of being killed or subjugated. By discrediting their usul (interpretive principles), the claims they make for an entire tradition are called into question.
\end{abstract}

Keywords: ISIS, Al-Qaeda, jihadism, terrorism, violent extremism, Khawarij, bay'ah, jizyah, takfirism, fiqh, usul al-fiqh, hermeneutics.

\section{Introduction}

Yusayr ibn "Amr narrates that he asked Sahl ibn Hunayf, "Did you hear the Prophet saying anything about the Khawarij?" Sahl said, "I heard him saying while pointing his hand towards Iraq: There will appear in it (i.e. Iraq) some people who will recite the Qur' an but it will not go beyond their throats, and they will go out from (leave) Islam as an arrow darts through the game's body." Prophet Muhammad spoke of this group with much disdain, while highlighting its inevitability and survival across ages.

Among the core features of the Kharijites was their expansion of interpretative frameworks giving them justification for violence. This is found in the description of 'Abd Allah ibn 'Umar, who stated that the Kharijites were those who took verses revealed about the disbelievers and assigned them to believers as an excuse for killing them. ${ }^{2}$ This does not just mean that Kharijites 
were guilty of unjust proclamations of takfir. It also demonstrates the looseness with which they interpreted verses about kuffar (disbelievers) as a whole in order to justify perpetual warfare against, in effect, anyone they wished to fight for political gain, including Muslims. As such, the expansion of rulings in regard to dealing with non-Muslims preceded the expansion of who should be considered to be a non-Muslim. It then became an interpretive framework that merely sought whatever decontextualised interpretation was possible to demonise and justify brutality against a political opponent.

Challenging these views requires both courage and sound scholarship. Amongst the most successful challengers to Kharijite thinking was 'Abd Allah ibn 'Abbas, the cousin of the Prophet, known as one of the most eminent early scholars of the Muslim ummah. With the appearance of the first Kharijites, he sought permission from Caliph 'Ali ibn Abi Talib to debate them. ${ }^{3}$ Ibn 'Abbas challenged the Kharijites on three major points. The first involved their misunderstanding of a verse in the Qur' an that forbade men to judge, reserving this for only God. In their interpretation, this verse referred to any judgment, even simple arbitration. But such an interpretation, Ibn 'Abbas highlighted, would contradict numerous other verses in the Qur' an (such as al-Maidah, 5:95) in which the ability of a man to judge between two parties is explicit. ${ }^{4}$ Secondly, Ibn 'Abbas challenged their criticism of "Ali regarding his failure to take war captives in the Battle of the Camel. Ibn "Abbas pointed to the fact that 'A'ishah, the wife of the Prophet, was present on the other side during this battle; if, as they suggested, 'Ali took her as a captive, then they would be closer to being disbelievers, because she is included among the Mothers of the Believers. ${ }^{5}$ Thirdly, Ibn 'Abbas rejected the Kharijite contention that, because 'Ali did not use the title Commander of the Believers, he might as well be Commander of the Disbelievers. 'Ali was attempting to unite all Muslims, even those who opposed him, and Ibn 'Abbas cited the fact that the Prophet erased the title "Messenger of God" from the treaty of Hudaybiyah for the greater goal of peace. Although Ibn 'Abbas' arguments were able to win over many from the Kharijites, their trend of thinking would continue throughout history, characterised by the repeated offense of utilising faulty usul to intentionally decontextualise and unduly expand traditional concepts in the service of violent ends.

Amongst such extremist groups in Muslim history, ISIS (the so-called Islamic State of Iraq and the Levant) is unique, as it has declared itself to be a 'state' and introduced modern aberrations of classical concepts, such as takfir, bay'ah (the pledge to the caliph by his followers), jizyah (the tax due upon religious minorities in exchange for protection), and dhimmah (the protected status of religious minorities in an Islamic state). Other earlier groups merely expanded 
the doctrine of jihad to include acts of terrorism. While al-Qaeda, for example, also employed takfir and bay'ah, they did so almost exclusively in terms of determining allegiance to Islam generally, and to their group specifically. Takfir was used by them to demote Muslim rulers from protected ruler status and civilians from protected civilian status. Bay'ah spoke to allegiance to the group by other sub-groups and fighters, as opposed to a demanded pledge from the average Muslim. However, ISIS arose with uniquely horrific forms of terror and expanded every possible term to extend its brutality and subjugation of those (primarily Muslims) within its reach. Terrorist groups that masquerade as flag-bearers of jihad today are not therefore monolithic. Although they commonly uphold certain core beliefs, such as viewing Islamic law through a lens of extreme violence, they differ markedly on details of ideology, thereby multiplying the sectarian factions amongst them.

A careful examination of extremist groups reveals that they have no interpretive framework matching any historical form of usul al-figh (principles of Islamic jurisprudence). Instead, they simply seek out the most violent possible interpretation of a text. Violence as an interpretive value is entirely foreign to traditional usul al-fiqh. The primary goal of the classical jurists was to seek the intent of God in matters of law, which for them required an insistence on being true to their usul. This perspective can be used to discredit the Islamic religious authority of modern extremists groups. This is especially important in the case of ISIS, which alleges to have revived the historical caliphate and establish a dar al-hijrah (land of migration, i.e. a place to escape with one's religion to safety and assured protection), both concepts of value to ordinary Muslims around the world. This paper accordingly examines the legal framework extremist groups use to justify their practices.

\section{ISIS, al-Qaeda and Jihad}

In February 2014, Abu Muhammad al-Maqdisi denounced ISIS as "hopelessly extremist and out of touch with reality." ${ }^{\prime \prime}$ In 2017, other religious scholars aligned with al-Maqdisi emphasised the tendency of ISIS towards "extreme violence and takfir," with some even likening them to Kharijites. ${ }^{7}$

Based on these statements, one may conclude that al-Maqdisi and his associates are moderates, at odds with the extremism extolled by ISIS. The reality, however, is that al-Maqdisi is the father of modern jihadist ${ }^{8}$ theory, whose books on jihad are widely read and cited among modern-day extremist groups. ${ }^{9}$ But, al-Maqdisi was not alone in his criticism of ISIS. Other prominent jihadist scholars joined him in their denunciation, including Abu Qatadah al- 
Filastini and Hani al-Siba'i. This reproach created a major public rift among jihadis, pitting the younger jihadist scholars supporting ISIS against the old guard supporting al-Qaeda. In reality, however, the split between the two sides dated back to at least 2005 and Ayman al-Zawahiri's letter to Abu Musab alZarqawi, criticising his indiscriminate attacks on Iraqi Shi' ah civilians. ${ }^{10}$

Likewise, in 2017, Sherman Jackson explored the surprisingly substantive critique and renunciation of ISIS by the former Egyptian leaders of al-Jama'ah al-Islamiyah, which invoked a number of violations of shariah (Islamic law). ${ }^{11}$ The value of so exploring the legalistic interpretive framework (or lack thereof) of ISIS and similar groups lies in its demonstration of just how foreign they are to Islam in its purest sense.

The scarcity of ISIS intellectual horsepower has been made evident by the fact that its top authority, Turki al-Bin'ali, is a 30-year old Bahraini scholar and prior student of al-Maqdisi. ${ }^{12}$ It seems that ISIS adopted much of al-Qaeda's formulations on jihad. Certainly, the majority of earlier well-known jihadi scholars came to prominence under the banner of al-Qaeda and other non-state jihadi movements. Therefore, it is not surprising that there is general agreement amongst both ISIS and al-Qaeda of the centrality of jihad (including suicide bombings) within Islamic practice. ISIS reiterates that jihad is an individual duty, and that offensive jihad should be pursued against apostate unbelievers in their own lands, "in order to make God's word most high and until there is no persecution." 13

Both al-Qaeda and ISIS make extensive use of the Qur'an, hadith, and sayings of medieval Islamic jurists to ground their opinions. Nearly every page of their publications feature references to various verses of the Qur'an and interpretations from well-known and widely respected exegetes and jurists, such as Ibn Taymiyah (1263-1328), Ibn Kathir (1300-1373), al-Qurtubi (1214-1273), and Ibn Hajar al-'Asqalani (1372-1449). ${ }^{14}$ This is an attempt to assert that they are a decidedly Sunni undertaking with no room for innovation (bid' $a h$ ), which they claim to be at the forefront of eradicating.

But while the similarities between ISIS and al-Qaeda are obvious, a number of differences in thought also exist between the organisations, notably relating to issues like takfir. The most significant differences, however, resulted from ISIS making the transition from jihadi group to state entity, with all the complexities that arose therefrom. In late 2007, Abu 'Umar al-Baghdadi officially dissolved al-Qaeda in Iraq (AQI) in favour of ISIS. Although, at the time, ISIS was rightfully considered a 'paper state', with nearly no territory, it grew under its subsequent leader, Abu Bakr al-Baghdadi, who was appointed in 2010. The new reality of statehood that ensued created a set of problems not previously encountered by a jihadi group, putting ISIS in need of new intellectual 
groundwork. Topics such as bay'ah, dhimmah, and the centralisation of jihad operations fell into this category.

\section{Bay'ah}

In January 2007, ISIS issued a dispatch entitled "Informing Mankind of the Birth of the Islamic State," which argued for the legitimacy of its new caliph, Abu 'Umar al-Baghdadi. ${ }^{15}$ In particular, it emphasised that the method by which Abu 'Umar al-Baghdadi had been elected was the shariah-based mechanism of bay'ah (oath of allegiance). The dispatch made the case that the only legal justification for assuming power in Islam rested with selection by an elite group of influential electors, known in classical figh as ahl al-hall wa'l- 'aqd (lit. those who loose and bind). While limiting the ahl al-hall wa'l- 'aqd to those waging jihad against the Americans and Shi'a in Iraq, ISIS claimed 60 percent of local Sunni tribal shaykhs had given their approval to the appointment of Abu 'Umar al-Baghdadi as caliph. ${ }^{16}$ Furthermore, Abu 'Umar al-Baghdadi was deemed qualified as head of state because he satisfied the seven qualifications of a caliph stipulated by shariah. ${ }^{17}$ But ISIS also argued that, as caliph, it became fard (religiously mandatory) for all other jihadi groups to give their bay'ah to Abu Umar al-Baghdadi. Soon thereafter reports began to emerge of the killing of jihadis who refused to give bay'ah to the ISIS leader.

As a result, a debate emerged between al-Qaeda affiliated jihadi scholars and ISIS regarding various types of bay'ah and their applicability in this specific case. In 2007, Osama bin Laden had supported ISIS (then still the Islamic State of Iraq, ISI) and urged other jihadi groups in Iraq to pledge their bay'ah to Abu 'Umar al-Baghdadi. But, since the state remained little more than a paper state, no serious legal discussion of bay'ah ensued. This lull continued into early 2012, when a reinvigorated ISIS, now under the leadership of its new caliph, Abu Bakr al-Baghdadi, expanded its efforts into Syria. This series of events caused the topic of bay'ah to resurface amongst jihadi scholars.

In 2013, a number of pro-ISIS scholars (including Abu Ja'far al-Hattab, Bin'ali, and Abu al-Hasan al-Azdi) brought a new angle to the dispute. There are, they said, two kinds of bay'ah in Islam: a 'restricted' bay'ah (given to the leader of a militant group for a limited term and only in matters of jihad) and an 'unrestricted' bay'ah (offered to a head of state for an unlimited term and unrestricted in scope). Abu Qatadah and al-Maqdisi issued statements against giving unrestricted bay'ah to Abu Bakr al-Baghdadi, arguing that ISIS lacked "political capability", 18 even though, back in 2007, bin Laden had argued against political capability as a condition for establishing the Islamic Emirate. He had 
said that, if that were so, "Islam would never achieve a state." In April of 2014, Turki al-Bin'ali wrote a 15-page rebuttal, outlining why political capability is a non-factor in determining the validity of ISIS. ${ }^{19}$

Finally, in a last-ditch effort to prevent ISIS expansion, Zawahiri brought an interesting intervention to the argument. He provided evidence that ISIS officials had previously given bay'ah to al-Qaeda in 2010 and that, therefore, Mullah 'Umar was in fact the rightful caliph. Since this appointment predated that of Abu 'Umar al-Baghdadi, ISIS was founded upon an invalid bay'ah. Although ISIS officials disavowed Zawahiri's claim, the damage was done. The split between pro-al-Qaeda and pro-ISIS constituents became pronounced, with Zawahiri's move even prompting some ISIS supporters to switch their allegiance to al-Qaeda. $^{20}$

Nevertheless, ISIS continued to use bay'ah as a tool of expansion. In late 2014, a series of bay'ah pledges were issued online via audio statements from jihadists in Saudi Arabia, Yemen, the Sinai Peninsula in Egypt, Libya and Algeria. Shortly thereafter, Abu Bakr al-Baghdadi accepted these pledges of support and declared ISIS territory had expanded into those areas. ${ }^{21}$ This move was only possible as a result of disavowing political capability as a requirement for the establishment of an Islamic State; the reality on the ground clearly continued to show that ISIS had no control whatsoever in those countries. But, according to Abu Bakr al-Baghdadi, the very fact someone from there had given him bay'ah was sufficient to expand his territory into those lands. Potentially, therefore, anyone in those lands who refused to obey the local ISIS-appointed 'governor' was rebelling against the state and could be captured, imprisoned, or even killed. While classical texts could be used to back this claim, the reality on the ground would differ starkly from the situations persisting at the time those texts were written. ${ }^{22}$

\section{The Issue of Takfir}

While al-Qaeda loosely applied takfir only to those it deemed to be associated with the West, ISIS used the term far more extensively, to the point that Zawahiri and al-Maqdisi criticised Zarqawi for targeting the Shi'a as apostates (below). In early jihadist works, this topic is treated in detail. Al-Qaeda in Iraq (AQI) cited the example of Abu Bakr, Islam's first caliph, and his fight against Arab tribes who refused to pay zakah (obligatory alms). Abu Bakr considered these tribes to be apostates based on their deeds, not words. By analogy, AQI argued that anyone who supported the American occupation of Iraq could be labelled as apostate. Defining "support for the occupation" in exceptionally 
general terms, they included anyone who assisted the occupiers, even verbally, including Muslims who may "have no thoughts against Islam, and there might be no suspicions surrounding him." ${ }^{23}$ In practical terms, this expansive definition enabled jihadists to justify the execution of nearly every Iraqi. Zarqawi further used this foundation to claim that all Shi'a were collectively apostates and could be killed without the shariah-sanctioned requisite opportunity for correction or repentance. This equated to a new, collective type of takfir in which an entire demographic could be deemed apostate.

This view had, however, been rejected years earlier by London-based jihadist, Abu Basir al-Tart usi. In his book Qawa'id fi takfir (Rules for Excommunication, 1994), Tartusi asserted that, even though a person may generally fall into unbelief or perform an act that is unbelief, such does not automatically equate to apostasy. In accordance with the known shariah mandate, each individual must go through rigorous due process before capital punishment is meted out. ${ }^{24}$

In an early ISIS publication, "Some of our Fundamentals" (2007), Abu 'Umar al-Baghdadi elucidated his view on apostates by stating:

We do not hereticise any Muslim who prays in the direction of our qibla [Mecca] on account of sins, such as fornication, drinking alcohol, and theft, so long as he does not consider it to be licit. Our position on faith is a middle way between the extremist Kharijites and the lax Murji'ites; whoso utters the two professions of faith and manifests to us Islam - so long as he does not engage in one of the nullifiers of Islam - we accord him the treatment accorded Muslims, and we entrust his soul to God, who is most high. [Our position on faith is furthermore] that unbelief is of two kinds, greater and lesser, and that a judgment [of unbelief] falls on whoever commits it [whether] in creed, word, or deed. However, expelling the specific individual among them and judging him to be destined for hell forever is conditional upon the establishment of the conditions of heresy (takfir) and the absence of factors prohibiting it. ${ }^{25}$

In this quote, Abu 'Umar al-Baghdadi seemingly agrees with Tartusi regarding the existence of a methodology for takfir. However, in the same article, Baghdadi deemed the leaders of those who participate in the political process (seemingly referring to the Muslim Brotherhood) as apostates, stating that in this respect there is no difference between a government official and a branch director. The masses that participate in the political process, however, can be excused based on ignorance. Also, apostasy can be extended to anyone who aids the occupiers in any way whatsoever. ${ }^{26}$ 
The $13^{\text {th }}$ issue of ISIS's English-language magazine, Dabiq, was dedicated to the topic of ra'fidah, a derogatory term used for the Shi' a. ${ }^{27}$ In the article, "The Rafidah, from Ibn Sana' to the Dajjal," the Shi'a were equated with Jews; their founder is identified as Ibn Saba' (a well-known hypocrite at the time of the Prophet Muhammad) and they are deemed apostate in their entirety. A section of the article entitled "The Rafidah According to the Jihad Claimants," was dedicated to discussing the opposing views of pro-al-Qaeda jihadists and ISIS regarding the apostasy of the Shi'a, with two pro-al-Qaeda jihadist positions being addressed. The first holds that the Shi' a cannot categorically be considered apostates due to the ignorance of the masses, while the second argues that past scholars did not make takfir of all Shi'a, but only those who went to extremes in theological matters. The ISIS response was that such subgroups are now extinct, and all current Shi'a are ra'fidah-those who curse the Prophet's companions and engage in grave worship. The authors of the article supported their stand with quotations from, among others, Muhammad ibn 'Abd al-Wahhab, Ibn Taymiyah, Muhammad ibn 'Abd al-Latif al-Shaykh and Shaykh Hamd alHumaydi. Zawahiri and al-Maqdisi, as well as the nationalist Taliban, were explicitly called out for their soft positions towards the Shi'a, being accused of perverting the truth and holding the deviant belief that Shi'a are Muslims. Finally, a long quote from Zarqawi's correspondence with Zawahiri concludes the argument that the Shi'a, due to their heretical beliefs and deviant practices, are apostates who need to be fought.

\section{Understanding the Jihadists' Interpretive Framework}

After reading many jihadist works, it is difficult to discern a shared, cohesive interpretive methodology, or $u s u l$. Claiming that they adopt a strict constructionist/ literalist orientation is too simplistic. Many jihadists have clearly utilised human reasoning when interpreting divine texts. But, since jihadists do not publish their hermeneutic methodology as pre-modern jurists did, we are left to analyse trends and interpretive patterns in their writings and speeches.

First, it is clear that they leverage the writings of pre-modern jurists as the foundation of their work. They take such writings out of context, however, allowing them to mix both conquest-style fatawa and anti-Crusader or antiMongol fatawa into their worldview. Their articles and speeches are awash with references to these fatawa, in many cases more often than references to the Qur'an and hadith.

Second, they filter out pre-modern scholars associated with heretical sects. This includes anyone connected to the Mu'tazilah, Murji'a, Khawarij, or any 
other group that, from the jihadist perspective, deviate from the 'straight path.' In essence, this creates a 'blessed list' of pre-modern scholars that one can select from, including the likes of al-Qurtubi, Ibn Taymiyah, and Ibn al-Qayyim, among others. Yet even among these, there may be differences of opinion, some of which contradict the jihadist programme.

A third principle, especially for pro-ISIS jihadists, is the selection of the most violent reading possible of a text from amongst the 'blessed list' of premodern scholars. The following examples illustrate the point:

1. Al-Mawardi provides multiple interpretations of verse 9:29 of the Qur' an regarding a non-Muslim's jizyah payments to the caliphate. The verse states that jizyah should be given "in a state of humiliation" (wa hum saghirun). Mawardi provides two opinions from classical exegetes regarding the meaning of "state of humiliation": it either means that dhimmis are lowly or that the laws of Islam apply to them. ${ }^{28}$ In The Study Qur'an, it states that the term was interpreted to mean that the jizyah should be rendered in a state of humility, but also identified an opinion that paying jizyah is itself tantamount to "being humbled". ${ }^{29}$ From among these opinions, the jihadists opt for the harshest, allowing the most brutal forms of subjugation of dhimmis in their territory.

2. Regarding the Islamic ruling on killing non-combatants during warfare, al- Zawahiri argues in "Jihad, Martyrdom and Killing of Innocents" that, in classical fiqh, there were three opinions on killing non-combatants: outright prohibition, outright legitimacy, and permissibility as long as there is a need or obligation to do so. Zawahiri favours the last opinion, seemingly the middle-ground opinion. But, further analysis reveals that these cases refer to extreme situations, such as when civilians are used as shields. Using these opinions to justify $9 / 11$-style attacks is clearly inappropriate and arguably leans towards the most violent interpretationor, at least, perceives a pre-modern interpretation through the lens of violence. $^{30}$

3. Regarding suicide operations, jihadists overrule the forbidding of suicide using past juristic opinions privileging human intentionality. Thus, premodern jurists justified a soldier putting himself in grave danger, even in cases where being killed was a near certainty. Using this as a foundation, jihadists have stated that there is a difference between killing oneself out of depression and hopelessness and killing oneself out of a noble sacrifice to further Islam. They therefore extend past juristic opinions to include 
suicide operations, even though it is clear such opinions did not address this issue. ${ }^{31}$ Of the different opinions on the matter, jihadists again opt for the most violent interpretation, contradicting the expected outcome of a literalist approach.

4. Jihadists insist that offensive jihad is a pillar of the religion. While it is true that the majority of pre-modern jurists accepted offensive jihad as a matter of pre-empting hostile action, Sufyan al-Thawri and Abu Hanifah took a different position. Thawri said: "Fighting against the associators (non-believers, i.e. those who associate others with God's divinity) is not an obligation unless they start the fight; then it is an obligation to fight back (against them)." On the other hand, al-Sarakshi and al-Shafi'i held the opinion that jihad must be waged until "all polytheists turn to Islam and all the People of the Book give the jizyah (the tax equivalent nonMuslim subjects pay to the Muslim state)." ${ }^{32}$ Of course, of these two opinions, jihadists opt for offensive jihad as an individual duty, but while adding that it includes "going after the apostate unbelievers by attacking [them] in their home territory, in order to make God's word most high and until there is no persecution." The term "persecution" is understood to refer to idolatry. ${ }^{33}$

5. Jihadists take the most violent opinion regarding the opportunity for repentance in the case of apostasy. Pre-modern jurists agreed that apostates have an opportunity to repent, that the Imam must invite them to the right path based on rational and textual evidence. Only after they have been given time and opportunity to repent can capital punishment be invoked. ${ }^{34}$ Contrary to mainstream opinion, however, AQI argued on the authority of Ibn Taymiyah that Muslims, when not in a position of power and control, should kill apostates without giving them an opport unity to repent. ${ }^{35}$ This is not only a likely misrepresentation of Ibn Taymiyah, but a dishonest elimination of the entire concept of repentance-based immunity.

\section{Countering Violent Extremism}

The reality of jihadist groups is that, while they masquerade as ideological, they are simply violent. They read violence into everything, while masking their dishonest interpretations with numerous supplementary texts that seemingly support their initially flawed conclusions. By exposing this flawed usul, their opinions are inherently discredited. 
The problem with programmes created to counter these groups, on the other hand, is that they are usually funded and administered by the same state actors that originated the violence and chaos that set the stage for terrorists groups to prosper. These same programmes are also often used to silence opponents, usually mainstream Muslim scholars and organisations that have earned the ire of state actors by standing between them and the appropriation of Islamic texts. Mainstream Muslim scholars and organisations will not hesitate to condemn the excesses of both Islamic terrorist groups and Muslim governments. In the process, they often become the targets of both. Moreover, some of the authors cited here offer outlooks on the history and ideology of jihadists that serve to validate the authority of ISIS, al-Qaeda, and the like by suggesting that their extrapolations are indeed orthodox. The community that upholds orthodoxy while rejecting these extrapolations are vulnerable to extremism and, therefore, must be heavily policed, paving the way for a deeply prejudicial industry that contributes to the same terror it claims to be combating. ${ }^{36}$

\section{Conclusion and Policy Recommendations}

After inspecting various jihadi views, the question naturally arises: are al-Qaeda and ISIS Islamic? Their extensive use of divine texts and respected medieval scholars might suggest the affirmative. Moreover, in a controversial March 2015 article in The Atlantic, entitled "What ISIS Really Wants," Graeme Wood stated: "The reality is that the Islamic State is Islamic. Very Islamic. Yes, it has attracted psychopaths and adventure seekers, drawn largely from the disaffected populations of the Middle East and Europe. But the religion preached by its most ardent followers derives from coherent and even learned interpretations of Islam. ${ }^{37}$ But, in the past jurists utilised a cohesive interpretive framework known as usul al-fiqh. As the theoretical and methodological system underlying the way legal norms and rules are derived and applied, usul includes topics such as the sources of legislation, how to resolve apparent conflicts in the divine texts, linguistics, and other interpretive methods. ${ }^{38}$ Violence (or even passivity for that matter) as an interpretive value is noticeably absent from any usul alfiqh work, past or present. It is for this reason that one may find a jurist holding opinions that seem to be harsh in one area and lenient in another. The primary goal of classical juristic activity was to seek the intent of God in matters of law, which required insistence on being true to usul. However, for modern-day jihadists, violence cannot be an explicit element of their interpretive framework, since it may contradict their own principles of hyper-textualism and of avoiding bid'ah (religious innovation), leaving them open to the criticism of inventing a 
new version of Islam. This demonstrates how groups like al-Qaeda and ISIS are inauthentic and incoherent in the legal sense.

Finally, this paper proposes the following policy recommendations to tackle the issue of violent interpretations of Islam in the modern world:

- Extremist groups such as al-Qaeda and ISIS commonly use classical texts to provide authoritative backing for their extremist actions and crimes against humanity. Thus, there is an urgent need to develop a new mechanism for identifying extremist groups by examining their methodology of violence. The construction of these guidelines should be through independent scholarly intervention, not that of governmental agencies or counter-terrorism programmes that only further stigmatise mainstream Muslims.

- Extremists and terrorists who perceive Islam through a lens of violence do not represent an authentic image of that religion. Extremism and militancy, by individuals or organisations, can be lessened through moderate understandings of authentic Islamic principles. Moderation and balance (wasatiyyah) must be implemented to achieve good governance in the Muslim World.

- Islam and terrorism must be brought into conversation with one another to defeat extremist groups that manipulate religion and create a wholesome understanding of how an Islamic society is meant to function.

- Defeating ISIS and other extremist groups will not guarantee the end of extremism and terrorism in the Muslim World. Rather, instead of replying to extremism with extremism, Muslim scholars should discredit extremist interpretations of Islam. Mainstream Muslim scholars and organisations should not hesitate to condemn the excesses of both supposedly Islamic terrorist groups and Muslim governments.

\section{Notes}

* Omar Suleiman is Founder and President of the Yaqeen Institute for Islamic Research, United States of America, and Professor of Graduate Liberal Studies at Southern Methodist University (email: omar@yaqeeninstitute.org).

** Elmira Akhmetova is Associate Professor at the Department of History and Civilisation, International Islamic University Malaysia, and Adjunct Associate Professor at the University of South Australia. She has published dozens of academic articles and books on Islamic history, interfaith dialogue, Islamic 
political thought and civilisational studies (email: eakhmetova@gmail.com and elmira@iium.edu.my).

1. Abu Abdullah Muhammad Bin Ismail al-Bukhari, Sahih al-Bukhari, vol. 9, trans. Muhsin Khan (Riyadh: Darussalam Pub. \& Distr., 1997), 52, hadith no. 6934.

2. Ibid., vol. 9, 49.

3. 'Abd al-Razzaq al-San'ani, Musannaf 'Abd al-Razzaq al-San'ani, vol. 10, $2^{\text {nd }}$ ed., ed. Habiburrahman A'zami (Beirut: al-Maktab al-Islami, 1983), 157, hadith no. 18678.

4. Ibn 'Abbas specifically cited this verse: "O you who believe, do not kill the game while you are in a state of Ihram, and whosoever of you kills it intentionally, then the penalty is an offering equivalent to the one he killed, as judged by two just men among you" (Q. al-Ma idah, 5:95). See Ahmad ibn al-Husayn al-Bayhaqi, Al-Sunan al-Kubra, vol. 8, ed. Muhammad 'Abd al-Qadir 'Ata (Beirut: Dar alKutub al-'Ilmiyah, 2003), 309, hadith no. 16740.

5. Q. Al-Ahzab, 33:6; Al-San'ani, Musannaf 'Abd al-Razzaq al-San'ani, vol. 10, 157, hadith no. 18676 .

6. Cole Bunzel, 'The Caliphate's Scholar-in-Arms,' Jihadica, 9 July 2014. Available at: http://www.jihadica.com/the-caliphate\%E2\%80\%99s-scholar-inarms/ (Accessed on: 25 November 2019).

7. Cole Bunzel, 'From Paper State to Caliphate: The Ideology of Islamic State,' The Brookings Project on U.S. Relations with the Islamic World, no.19 (March 2015), 30 .

8. The terms jihadist and jihadism are usually applied to these groups, yet a practicing Muslim will naturally find them objectionable due to the implied misuse of the doctrine of jihad. The term is retained here only because of its prevalence in the academic literature.

9. William F. McCants and Jarret Brachman, Militant Ideology Atlas: Research Compendium (New York: Combating Terrorism Center, 2006), 333. The Militant Ideology Atlas is a project that identifies influential jihadi thinkers through "citation analysis." There is a problem with this metric, however, in that it fuels many racist Countering Violent Extremist initiatives. It is cited here simply for this data point.

10. Wladimir van Wilgenburg, "“Fight Them Until There Is No Fitnah": The Islamic State's War with al-Qaeda,' Terrorism Monitor, vol. 13, i. 4 (20 February 2015). Available at: https://jamestown.org/program/fight-them-until-there-is-no-fitnahthe-islamic-states-war-with-al-qaeda/ (Accessed on: 25 November 2019).

11. Sherman Jackson, 'Fundamentalist vs. Fundamentalist: An Islamist Critique of ISIS,' YouTube 1:12, Department of Religious Studies at McMaster University. Available at: https://youtube.com/watch?v=A1Gj_tOHGz4 (Accessed on: 25 November 2019).

12. Bunzel, 'From Paper State to Caliphate,' 11.

13. Ibid., 10.

14. Often times, pre-modern jurists are referred to as a means of promoting the Islamic authenticity of a specific opinion, perhaps because they pre-date the advent of colonialism in Muslim lands.

15. Uthman ibn Abd al-Rahman al-Tamimi, Ilam al-anam bi-milad Dawlat al-Islam 
(Informing Mankind of the Birth of the Islamic State) (Muassasat al-Furqan, 2007), 41 .

16. Bunzel, 'From Paper State to Caliphate,' 18-9.

17. In classical fiqh, the seven conditions to the Caliphate are: 1. A just nature, 2. Knowledge of ijtihad (independent legal reasoning), 3. Good health, 4. Sound limbs, 5. Capable judgement for administration, 6. Courage and bravery, 7. Of the family of the Quraysh (al-Mawardi 12)

18. Bunzel, 'From Paper State to Caliphate,' 26-7.

19. Turki al-Bin'ali, Al-Qiyafah fi 'Adam Ishtirat al-Tamkin al-Kamil li al-Khilafah (Baghdad: Islamic State in Iraq and Sham, n.d).

20. A notable example is Abu al-Mundhir al-Shinqiti, an anonymous Mauritanian scholar who initially supported ISIS's claim to have established a state and not just a battlefield command. Later, Shinqiti changed his stance after learning of Zawahiri's claim that Mullah 'Umar was in fact the first caliph, countering claims that Mullah 'Umar was disqualified because he was not from the tribe of Quraysh. Several ISIS supporters responded with a series of lectures and papers. See Bunzel, 'From Paper State to Caliphate,' 34.

21. Ibid.,' 32.

22. ISIS has also expanded to "virtual bay'ahs," as discussed by Philipp Holtman: “In IS' vision, online bay'at, i.e. given or documented online, are supposed to stimulate rites of passage, which immerse IS-sympathisers ever deeper into jihadi ideology and increase a feeling of shared brotherhood, communality and obedience, eventually turning them into active supporters and actors. IS hopes that the feeling of obligation will create enough psychological pressure to lead to single attacks, such as lately in Ottawa, Canada." See Philipp Holtmann, 'Different Functions of IS Online and Offline Pledges (bay'at): Creating a Multifaceted Nexus of Authority,' Jihadology, 15 November 2014. Available at: https://jihadology.net/2014/11/15/guest-post-the-different-functions-of-isonline-and-offline-plegdes-bayat-creating-a-multifaceted-nexus-of-authority/ (Accessed on: 25 November 2019).

23. Mohammed M. Hafez, 'The Alchemy of Martyrdom: Jihadi Salafism and Debates over Suicide Bombings in the Muslim World,' Asian Journal of Social Science 38, no. 3 (2010): 367.

24. See ibid., 369: "Tartusi lists eight conditions that preclude individual charges of takfir even when it is obvious that the actions or beliefs of the individual involved constitute unequivocal cardinal sins, generally speaking. These can be summarised as lacking proper knowledge of what constitutes cardinal sins in Islam due to lack of mental maturity associated with young age, retardation, or insanity; ignorance, misunderstanding, and misinterpretation of the proper doctrine, or improper socialisation in the faith; coercion by unbelievers; and dilemmas in which believers have to choose between greater and lesser forms of impiety."

25. Bunzel, 'From Paper State to Caliphate,' 38.

26. Ibid., 39 .

27. ISIS, 'Dabiq 13,' Islamic State in Syira and Sham, 1 February 2016. ISIS differentiates between the Shi'a and the ra'fidah. The Shi'a constitute a more general category, including the extinct sect of people who historically preferred 
'Ali over Abu Bakr as first caliph (yet while still accepting the latter's caliphate as legitimate). The ra'fidah, on the other hand, are those who curse the sahabah (the Prophet's companions) and participate in grave worship.

28. 'Ali ibn Muhammad al-Mawardi and Asadullah Yate (trans.), Al-Ahkam AsSultaniyyah: The Laws of Islamic Governance (London: Ta-Ha Publ, 1996), 208.

29. Seyyed H. Nasr (ed.), The Study Quran: A New Translation and Commentary (New York: HarperOne, 2017), 426, verse 9:29.

30. See Hafez, 'The Alchemy of Martyrdom', 374. Other jihadists, such as al-Maqdisi and Tartusi, disavowed the killing of non-combatants. They explained that classical texts take extreme caution concerning the harming of non-combatants, only allowing it in extreme circumstances. Tartusi's line of argumentation is that the well-known shar' $i$ evidence prohibiting the taking of a life is unequivocal (qat'iyah). The use of divine texts that are subject to multiple interpretations cannot override such unequivocal evidence - the rulings of fallible human beings cannot override the commands of an infallible Creator.

31. Ibid., 371.

32. Abdul Hamid A. Abu Sulayman, Towards an Islamic Theory of International Relations: New Directions for Methodology and Thought (New Delhi: Al-Ittehad Publications, 2010), 9-10.

33. Bunzel, 'From Paper State to Caliphate,' 10.

34. Wael B. Hallaq, Sharia: Theory, Practice and Modern Transformations (Edinburgh: Cambridge Press, 2009), 319.

35. Hafez, 'The Alchemy of Martyrdom,' 367. On this issue, Zawahiri rebuked Zarqawi in a 2005 letter, where he states: "And if the attacks on Shia leaders were necessary to put a stop to their plans, then why were there attacks on ordinary Shia? Won't this lead to reinforcing false ideas in their minds, even as it is incumbent on us to preach the call of Islam to them and explain and communicate to guide them to the truth?" See West Point Combating Terrorism Center's, "Zawahiri's Letter to Zarqawi," Available at: https:/ctc.usma.edu/ harmony-program/zawahiris-letter-to-zarqawi-original-language-2/ (Accessed on: 25 November 2019).

36. Younis, Tarek, 'Counter-Radicalisation: A Critical Look into a Racist New Industry,' Yaqeen Institute, March 2019. Available at: https://yaqeeninstitute.org/ tarekyounis/counter-radicalization-a-critical-look-into-a-racist-new-industry/\#. Xdw2_ZNKg1h (Accessed on: 25 November 2019)

37. Graeme Wood, 'What ISIS Really Wants,' The Atlantic, March 2015. Available at: https:/www.theatlantic.com/magazine/archive/2015/03/what-isis-reallywants/384980/ (Accessed on: 25 November 2019).

38. Hallaq, Sharia, 50-65. 